\title{
IAMJ
}

INTERNATIONAL

AYURVEDIC

MEDICAL JOURNAL

\section{PREVALENCE, PATHOGENESIS, CLASSIFICATION, IMAGING, SCREENING AND MANAGE-MENT OF DIABETIC RETINOPATHY- A CRITICAL REVIEW}

\author{
Narender Chanchal ${ }^{1}$, Kushagra Goyal ${ }^{2}$, Divya Vij ${ }^{3}$, Rajesh Kumar Mishra ${ }^{4}$ \\ ${ }^{1}$ Assistant Professor, Department of Shalakya Tantra, Kunwar Shekhar Vijendra Ayurveda Medical College \& \\ Research Centre, Shobhit University, Gangoh, Saharanpur, Uttar Pradesh, India \\ ${ }^{2}$ Assistant Professor, Department of Agadatantra, Kunwar Shekhar Vijendra Ayurveda Medical College \& \\ Research Centre, Shobhit University, Gangoh, Saharanpur, Uttar Pradesh India \\ ${ }^{3}$ Assistant Professor, Patanjali BharatiyaAyurvigyanEvumAnusandhanSansthan. Haridwar, Uttarakhand, India \\ ${ }^{4}$ Assistant Professor, Patanjali BharatiyaAyurvigyanEvumAnusandhanSansthan. Haridwar, Uttarakhand, India
}

Corresponding Author: drnarenderchanchal02051993@gmail.com

https://doi.org/10.46607/iamj1709072021

(Published Online: July 2021)

Open Access

(C) International Ayurvedic Medical Journal, India 2021

Article Received: 14/06//2021 - Peer Reviewed: 24/06/2021 - Accepted for Publication: 25/06/2021

\section{Check for updates}

\section{ABSTRACT}

Diabetic retinopathy is that the leading reason for sightlessness among people between twenty-five and seventyfour years older within the industrialised world. Diabetes mellitus (DM) includes a heterogeneous cluster of disorders of carbohydrate, protein, and metastasis manifesting hyperglycemia. Diabetic retinopathy could be microangiopathy ensuing from the chronic effects of the disease, and shares similarities with the microvascular alterations that occur in different tissues at risk of DM equivalent to the kidneys and also the peripheral nerves. Diabetic retinopathy is assessed into nonproliferative and proliferative stages. Nonproliferative diabetic retinopathy (NPDR) involves progressive intraretinal microvascular alterations that may result in, and a lot of advanced proliferative stages outlined by extraretinal neovascularization. Imaging modalities in common clinical use for the management of NPDR and DME embrace structure photography, fluorescein angiography (FA), and optical coherence tomography (OCT). The suggested schedule for screening and surveillance for NPDR reflects data concerning the epidemiology and natural history of the disease. Diabetic retinopathy could be a leading explanation 
for vision loss in working-age Americans and a major cause of sightlessness worldwide. The International Diabetes Federation estimates that as several as 592 million individuals worldwide can have DM in 2035, a rise from or so 387 million people calculable to possess the disease in 2014. Here, we tend to present a review of the present understanding and new insights into biochemical mechanisms within the pathological process in DR, classification, furthermore as clinical treatments for DR patients.

Keywords: Diabetic retinopathy, diabetes mellitus, retinal degeneration, fluoresces in angiography, optical coherence tomography, VEGF, focal/grid laser photocoagulation.

\section{INTRODUCTION}

Diabetic retinopathy is that the leading reason for sightlessness among people between twenty-five and seventy-four years archaic within the industrialised world. It affects 3 out of 4 diabetic patients when fifteen years of disease duration. Chronic hyperglycemia is the primary issue resulting in the event of diabetic retinopathy and alternative complications of the disease. The importance of long-run glycemic management has been once and for all established in the landmark clinical trials as well as the diabetes control and Complications Trial (DCCT) ${ }^{[1]}$, and therefore the United Kingdom Prospective Diabetes Study (UKPDS) ${ }^{[2-3]}$ Duration of diabetes diagnosis, hypertension, elevated haemoglobin A1C, and male sex are robust risk factors for the event of diabetic retinopathy ${ }^{[4-6]}$. Diabetic retinopathy is classed into nonproliferative and proliferative stages. Nonproliferative diabetic retinopathy (NPDR) involves progressive intraretinal microvascular alterations which will result in a lot of advanced proliferative stages outlined by extraretinal neovascularization. The earliest diabetesinduced changes within the retina are biochemical, hemodynamic, and cellular. Usually, these changes are at first impalpable clinically and should have not any or least result on vision. In contrast, proliferative diabetic retinopathy (PDR) represents a complicated stage of the diabetic disease characterised by the expansion of recently shaped retinal vessels on the retina or blind spots that stretch on the retinal surface or into the vitreous cavity, considerably increasing the danger for vision loss ${ }^{[7-8]}$.

\section{Prevalence of Retinopathy:}

With type 1 diabetes, $13 \%$ of patients have retinopathy at five years, and $90 \%$ after $10-15$ years. The pro- liferative retinopathy develops in $25 \%$ of type 1 diabetic after fifteen years ${ }^{[9]}$. Insulin-treated patient with type 2 diabetes features a $40 \%$ prevalence of retinopathy after 5 years, and $24 \%$ if treated with oral hypoglycemic agents. When fifteen- nineteen years of diabetes, the prevalence will increase to $84 \%$ and $53 \%$ respectively. Proliferative retinopathy is present in $2 \%$ of type 2 patients at intervals the 5 years of diagnosing and in twenty-five per cent 25 years or additional ${ }^{[10]}$. Population-based studies like the Wisconsin epidemiologic Study of Diabetic Retinopathy (WESDR) ${ }^{[11-13]}$.

\section{Biochemical Mechanisms in the Pathogenesis of Diabetic Retinopathy:}

Chronic hyperglycemia is understood to be the most important etiologic issue resulting in all the microvascular complications of diabetes, as well as diabetic retinopathy. However, the organic chemistry mechanisms by that hyperglycemia act presently stay unclear. Projected theories are mentioned during this article.

\section{The Aldose Reductase Theory:}

Elevation of intracellular aldohexose levels will cause enhanced activation of the monosaccharide reductase pathway. Monosaccharide reductase uses the reduced variety of nicotinamide adenine dinucleotide phosphate (NADPH) as a chemical compound to scale back several aldose sugars into their various sugar alcohols. Aldohexose is reduced to sorbitol, which is then oxidised into fruit sugar by sorbitol dehydrogenase. However, sorbitol could build up to high intracellular levels as a result of the sorbitol dehydrogenase reaction is slow and therefore the accumulating sorbitol doesn't simply cross the cytomembrane into 
the extracellular space. In normoglycemic conditions, the monosaccharose enzyme pathway is nonoperative as a result of aldohexose may be a poor substrate for aldose reductase because of its high binding constant $(\mathrm{kM})$. However, within the setting of hyperglycemia, the aldose reductase pathway becomes activated once the opposite protein pathways of glucose metabolism become saturated. Lens epithelial tissue expresses high levels of aldose reductase, and accumulation of sorbitol is believed to guide the event of a cataract in diabetes ${ }^{[14]}$. Diffusion stresses are planned because the mechanism by that elevated animate thing sorbitol results in the pathologic changes seen in diabetes [15].

\section{Advanced Glycation Endproduct (Age) Theory}

Advanced glycation endproducts (AGEs) is that the collective name given to proteins, lipids, and nucleic acids that endure irreversible modification by reducing sugars or sugar-derived products. The series of chemical processes that result in the formation of AGEs is named the Maillard reaction. The Maillard reaction is to blame for the "browning" of tissue seen with ageing also because of the "browning" of food throughout cooking. The initial chemical reaction is thought of as early glycation and involves reversible accelerator binding of sugar to aminoalkanoic acid teams on proteins, lipids, or nucleic acids. They form Schiff bases which might bear arrangements to make additional stable Amadori merchandise. Glycosylated $\mathrm{Hb}(\mathrm{HbA} 1 \mathrm{c})$ and fructosamine are well-known samples of Amadori products used clinically as markers of glycemic control. Though they are not AGEs, they will undergo any reactions to eventually cause the formation of AGEs. The formation of AGEs may directly harm cells by impairing the performance of a range of proteins ${ }^{[16]}$, as well as each animate thing proteins like albuminoidal ${ }^{[17]}$ and animate thing proteins. ${ }^{[18-19]}$.

\section{Photoreceptor Metabolism Theory:}

Rods expend a lot of energy darkly, requiring up to fourfold the maximum amount of adenosine triphosphate (ATP) in darkness compared to light. Reports have theorized that dark-adapted rods could also be concerned with the development of retinal chronic disease, as well as diabetic retinopathy ${ }^{[20]}$. Within the dark-adapted state, rods consume high levels of chemical elements, therefore, reducing the PO2 of the inner retina. Hyperglycaemia leads to pseudohypoxia of the retina and matched with hypoxia of the inner retina throughout the dark-adapted state, VEGF production is increased. ${ }^{[20-22]}$.

\section{Reactive Oxygen Intermediates (Roi) Theory:}

One of the oldest theories proposes that chronic hyperglycaemia results in the complications of polygenic disorder by increasing aerophilous stress. The standard metabolic pathway of aldohexose is through the metabolic process and therefore the tricarboxylic acid cycle, which takes place within the mitochondria and yields reducing equivalents accustomed to driving the synthesis of nucleotide via oxidative phosphorylation. However, byproducts of the biological process embrace free radicals, similar to superoxide anion, whose production is hyperbolic by high levels of aldohexose ${ }^{[23]}$. Free radicals will injury mitochondrial DNA ${ }^{[24]}$ moreover as cellular proteins ${ }^{[25]}$ and is created by the autoxidation of glucose.

\section{Protein Kinase C (PKC) Theory:}

PKC may be an omnipresent catalyst that seems to push the event of many of the complications of diabetes while not the involvement of the monosaccharide enzyme pathway. It has been determined that diabetes and inborn error of metabolism will manufacture elevation of DAG inside cells of the retina and artery in dogs despite treatment with the aldose reductase substance sorbinil [26-27]. Activation of PKC happens through the activation of phospholipase $\mathrm{C}$ that results in a rise in animate thing $\mathrm{Ca} 2+$ and $\mathrm{DAG}$, which successively results in the activation of PKC ${ }^{[28]}$. Hyperglycaemia may end up in pathologic activation of PKC. Elevated aldohexose levels lead to activation of the glycolytic pathway and cause raised levels of intracellular glyceraldehyde-3-phosphate. Glyceraldehyde-3-phosphate will promote the American state Novo synthesis of DAG through glycerol-3- phosphate, which in turn activates PKC ${ }^{[29]}$.

\section{Classification of Diabetic Retinopathy:}

The ETDRS diabetic retinopathy severity scale was evaluated for its reliability as a part of the study and 
was valid as a grading system with prognostic power ${ }^{[30-32]}$. ETDRS investigators assigned thresholds to outline delicate NPDR, moderate NPDR, severe NPDR, early PDR, and risky PDR.

Classification of Diabetic Retinopathy in the Early Treatment of Diabetic Retinopathy Study (ETDRS):

Mild NPDR: A minimum of one microaneurysm, AND criteria not met for a lot of severe retinopathy.

Moderate NPDR: Hemorrhages/microaneurysms $\geq$ commonplace photograph 2A AND/OR cotton-wool spots, venous beading, or IRMA positively present; AND criteria not met for more severe retinopathy.

Severe NPDR: Cotton-wool spots, venous beading, and IRMA positively present in a minimum of 2 of photographic fields 4-7; OR two of the 3 preceding options presents in at least two of fields 4-7 and haemorrhages/microaneurysms present in fields 4-7 $\geq$ normal photograph $2 \mathrm{~A}$ in at least one among them; OR IRMA present in every of fields $4-7$ and $\geq$ standard photograph 8A in at least two of them; AND criteria not met for additional severe retinopathy.

Early PDR: New vessels; AND criteria not met for high-risk PDR.

High-risk PDR: New vessels on or inside one disc diameter of the point (neovascularization of the disc $[\mathrm{NVD}]$ ) $\geq$ commonplace photograph 10A (approximately - disc area) with or while not vitreous or preretinal haemorrhage; OR vitreous and/or preretinal haemorrhage during new vessels, either NVD < standard photograph $10 \mathrm{~A}$ or new vessels elsewhere $(\mathrm{NVE}) \geq$ disc area.

\section{Diabetic Macular Edema:}

DME, outlined as macular thickening ensuing from diabetic retinopathy, results from retinal tube-shaped structure hyperpermeability and different alterations within the retinal microenvironment and represents a standard reason behind vision loss among individuals with DM. DME will occur in eyes with a large spectrum of underlying retinopathy, from delicate NPDR to PDR. DME may result from the leak of microaneurysms, or it should evolve from diffuse leakage of hyperpermeable capillaries.

\section{Ancillary Ocular Imaging:}

Imaging modalities in common clinical use for the management of NPDR and DME embrace fundus photography, fluorescein angiography (FA), and optical coherence tomography (OCT).

\section{Fundus Photography:}

Fundus photography may be a valuable clinical tool for evaluating the progression of retinopathy in individual patients and participants in clinical trials. Photography is employed in clinical follow to document the standing of retinopathy and the effects of treatment. Although not forever as sensitive as ophthalmoscopy at detection delicate options of diabetic retinopathy similar to IRMA and early extraretinal neovascularization, photography is often helpful in documenting bound findings in choose patients. For example, it can be accustomed to record the extent and distribution of hard exudates in DME, the extent of retinal alterations in severe NPDR, and also the look of laser photocoagulation burns.

\section{Fluorescein Angiography:}

Fluorescein angiography (FA), consisting of photography or videography of the fundus exploitation cameras equipped with acceptable filters following intravenous injection of the organic compound dye fluorescent dye metallic element, has been used clinically in ophthalmology for over fifty years. Fluorescein angiography has multiple uses within the clinical analysis of diabetic retinopathy. As a result of intravenous injection of fluorescein sodium are often related to severe adverse reactions (with risk of death calculable at around 1/200, 000) ${ }^{[33]}$, Fluorescein angiography for evaluation of diabetic retinopathy is confined to settings within which vital aspects of management depend on the results of the test. Fluorescein angiography has been used extensively for the evaluation of diabetic retinopathy, In NPDR; Fluorescein angiography is most typically indicated for additional characterization of DME diagnosed on ophthalmoscopy.

\section{Optical Coherence Tomography:}

OCT, which utilizes low-coherence interferometry involving close to infrared emission for crosssectional imaging of intraocular structures, has 
emerged over the last 20 years as a fast; non-invasive means that of imaging the retina, vitreoretinal interface, and also the retinal pigment epithelial tissue (RPE) in NPDR and alternative macular diseases. The fundamental principles of Optical Coherence Tomography and the applications of this technology to the analysis of the retina In NPDR, Optical Coherence Tomography is usually accustomed to characterize DME and abnormalities of the vitreoretinal interface.

\section{Management:}

\section{Pharmacotherapy with Vascular Endothelial Growth Factor (VEGF) Antagonists:}

VEGF-A exerts potent effects on retinal vascular permeability, and concentrations of sure VEGF-A isoforms within the retina and vitreous are elevated in diabetic retinopathy ${ }^{[34-36]}$. Numerous VEGF antagonists are developed for ophthalmic andnonophthalmic uses, as well as bevacizumab, a humanized murine antibody binding VEGF-A; ranibizumab, a humanized murine monoclonal antibody fragment, additionally binding VEGF-A; pegaptanib sodium, an aptamer specifically inhibiting the VEGF-A one hundred sixty-five isoform; and aflibercept, an individual's fusion super molecule incorporating ligandbinding components from VEGF receptors and also the $\mathrm{Fc}$ region of an $\mathrm{IgG1}$ molecule. Endogenous administration for ophthalmic illness has been studied for a few agents ${ }^{[37-39]}$, however intravitreous injection has become the quality route of delivery to the eye.

\section{Pharmacotherapy with Corticosteroids:}

Corticosteroids have immune-modulatory and antiangiogenic properties and are used for the treatment of ophthalmic disease since the Nineteen Fifties ${ }^{[40-45]}$. Common adverse effects, as well as hyperglycaemia and different metabolic alterations tough to manage within the setting of DM, limit their long-run general use, however, a variety of formulations permitting native delivery to the eye have been developed. The restricted intraocular penetration of existing topical preparations makes them unsuitable for the treatment of most retinal diseases, but injectable corticosteroids and sustained-release formulations for intraocular use have been evaluated for effectuality in DME.

\section{Focal/Grid Laser Photocoagulation:}

The effectiveness of focal/grid laser photocoagulation for treatment of DME was established within the ETDRS,${ }^{[46]}$ the impact of various methods of focal/grid and scatter laser photocoagulation and therefore the use of daily salicylate on retinopathy progression and vision loss in eyes with malady starting from gentle NPDR to early (non-high-risk) PDR ${ }^{[47]}$. The present normal technique is well summarized by parameters for "modified-ETDRS" focal/grid laser photocoagulation such that by the DRCR.net to be used in its protocols. (Table 1)

Table 1: Modified-ETDRS Focal/Grid Laser Photocoagulation Technique Used By the Diabetic Retinopathy Clinical Research Network (DRCR.Net):

\begin{tabular}{|l|l|}
\hline Treatment Parameter & DRCR.net Technique for Modified-ETDRS Focal/Grid Laser Photocoagulation \\
\hline Direct treatment & $\begin{array}{l}\text { Directly treat all leaking microaneurysms in areas of retinal thickening between } 500 \text { and } 3000 \\
\mu \mathrm{m} \text { from the centre of the macula (although may treat between } 300 \text { and } 500 \mu \mathrm{m} \text { of the centre if } \\
\text { centre-involved oedema persists after initial focal photocoagulation, but generally not if the vis- } \\
\text { ual acuity is better than 20/40) }\end{array}$ \\
\hline $\begin{array}{l}\text { Change in microaneu- } \\
\text { rysm colour with direct } \\
\text { treatment }\end{array}$ & \begin{tabular}{l} 
Not required, but at least a mild grey-white burn should be evident beneath all microaneurysms \\
\hline $\begin{array}{l}\text { Spot size for direct treat- } \\
\text { ment }\end{array}$
\end{tabular} \\
\hline $\begin{array}{l}\text { Burn duration for direct } \\
\text { treatment }\end{array}$ & $0.05-0.1$ seconds \\
\hline $\begin{array}{l}\text { Grid treatment } \\
\text { Apply to all areas with oedema not associated with microaneurysms; if fluorescein angiography } \\
\text { is obtained, the grid is applied to areas of oedema with angiographic nonperfusion when judged }\end{array}$ \\
\hline
\end{tabular}




\begin{tabular}{|l|l|}
\hline $\begin{array}{l}\text { The area considered for } \\
\text { grid treatment }\end{array}$ & $\begin{array}{l}\text { indicated by the investigator } \\
\text { porally from the macular centre; no burns placed within } 500 \mu \mathrm{m} \text { of disc }\end{array}$ \\
\hline $\begin{array}{l}\text { Burn size for grid treat- } \\
\text { ment }\end{array}$ & $50 \mu \mathrm{m}$ \\
\hline $\begin{array}{l}\text { Burn duration for grid } \\
\text { treatment }\end{array}$ & $0.05-0.1$ seconds \\
\hline $\begin{array}{l}\text { Burn intensity for grid } \\
\text { treatment }\end{array}$ & Barely visible (light grey) \\
\hline $\begin{array}{l}\text { Burn separation for grid } \\
\text { treatment }\end{array}$ & Two visible burn widths apart \\
\hline $\begin{array}{l}\text { Wavelength (grid and } \\
\text { direct treatment) }\end{array}$ & Green to yellow wavelengths \\
\hline
\end{tabular}

\section{Panretinal Photocoagulation:}

The initial reports regarding photocoagulation were restricted by little numbers of patients, transient periods of follow-up or lack of an at random way\} designated management cluster ${ }^{[48]}$. The National Eye Institute' Diabetic Retinopathy Study (DRS), which compared Xe arc and argon laser photocoagulation to no photocoagulation in patients with PDR ${ }^{[49]}$. The DRS provided the initial proof to determine the protection and effectiveness of recent pan-retinal (scatter) photocoagulation (PRP).

Current Techniques of Panretinal Photocoagulation: The DRS and ETDRS valid the effectiveness of PRP and established the indications and parameters for the treatment of PDR many decades ago [50-51]. These ideas persist largely unchanged in the present day as a result of their exceptional efficacy. An outline of the current protocol for PRP is conferred (Table 2).

Table 2: Current Treatment Protocol for Panretinal (PRP) Laser Photocoagulation:

\section{Burn Characteris- Recommendations \\ tic \\ CONVENTIONAL SLITLAMP LASER DELIVERY SYSTEMS}

Size (on the retina) $\quad 500 \mu \mathrm{m}$ (e.g., argon laser using 200- $\mu \mathrm{m}$ spot size with Rodenstock lens, or equivalent), $400 \mu \mathrm{m}$ (e.g., $200-\mu \mathrm{m}$ spot size with Mainster 165, Volk Quadraspheric or SuperQuad 160) or 500- $\mu \mathrm{m}$ spot size with 3-mirror contact lens

\begin{tabular}{l|l}
\hline Exposure & 0.1 seconds recommended, $0.05-0.2$ allowed \\
\hline Intensity & Mild white retinal burns (i.e., 2+ to 3+ burns)
\end{tabular}

Distribution $\quad$ Edges 1 burn width apart

No. of ses- 1 to 3

sions/sittings

Nasal proximity to No closer than $500 \mu \mathrm{m}$

the disc

Temp. proximity to No closer than $3000 \mu \mathrm{m}$

centre

\begin{tabular}{l|l} 
Superior/inferior & No further posterior than 1 row within the temporal arcades
\end{tabular}

limit

\begin{tabular}{l|l} 
Extent & Arcades $(\sim 3000 \mu \mathrm{m}$ from the macular centre $)$ to at least the equator
\end{tabular}

Several final burns: $\quad 1200-1600$

\begin{tabular}{l|l} 
Wavelength & Green or yellow (red can be used if the vitreous haemorrhage is present precluding use of green or
\end{tabular} 


\begin{tabular}{|c|c|}
\hline & yellow) \\
\hline \multicolumn{2}{|c|}{ AUTOMATED PATTERN SCANNING LASER DELIVERY SYSTEMS } \\
\hline Size (on the retina) & $400 \mu \mathrm{m}$ (e.g., $200 \mu \mathrm{m}$ spot size with Mainster 165, Volk Quadraspheric or SuperQuad 160) \\
\hline Exposure & 0.02 seconds \\
\hline Intensity & Mild white retinal burns \\
\hline Distribution Edges & 0.5 burn width apart \\
\hline $\begin{array}{l}\text { No. of ses- } \\
\text { sions/sittings }\end{array}$ & Unrestricted (generally should be completed in $<6$ ) \\
\hline $\begin{array}{l}\text { Nasal proximity to } \\
\text { the disc }\end{array}$ & No closer than $500 \mu \mathrm{m}$ \\
\hline $\begin{array}{l}\text { Temp. proximity to } \\
\text { centre }\end{array}$ & No closer than $3000 \mu \mathrm{m}$ \\
\hline $\begin{array}{l}\text { Superior/inferior } \\
\text { limit }\end{array}$ & No further posterior than 1 row within the temporal arcades \\
\hline Extent & Arcades $(\sim 3000 \mu \mathrm{m}$ from the macular centre) to at least the equator \\
\hline $\begin{array}{l}\text { Number of final } \\
\text { burns }\end{array}$ & $1800-2400$ \\
\hline Wavelength & Green $(532 \mathrm{~nm})$ only \\
\hline Patterns & $2 \times 2,3 \times 3,4 \times 4,5 \times 5$ as needed for uniform focus/uptake \\
\hline \multicolumn{2}{|c|}{ INDIRECT LASER DELIVERY SYSTEMS } \\
\hline Size (on the retina) & $\begin{array}{l}400 \text { to } 500 \mu \mathrm{m} \text { spot size with } 20 \mathrm{D}, 28 \mathrm{D} \text {, or } 30 \mathrm{D} \text { indirect lens (depending on diopter of the indirect } \\
\text { lens) }\end{array}$ \\
\hline Exposure & $0.050-0.10$ seconds \\
\hline Intensity & Mild white retinal burns \\
\hline Distribution & Edges 1 burn width apart \\
\hline $\begin{array}{l}\text { No. of ses- } \\
\text { sions/sittings }\end{array}$ & Unrestricted (generally should be completed in $<6$ ) \\
\hline $\begin{array}{l}\text { Nasal proximity to } \\
\text { the disc }\end{array}$ & No closer than $500 \mu \mathrm{m}$ \\
\hline $\begin{array}{l}\text { Temp. proximity to } \\
\text { centre }\end{array}$ & No closer than $3000 \mu \mathrm{m}$ \\
\hline $\begin{array}{l}\text { Superior/inferior } \\
\text { limit }\end{array}$ & No further posterior than 1 row within the temporal arcades \\
\hline Extent & Arcades $(\sim 3000 \mu \mathrm{m}$ from the macular centre) to at least the equator \\
\hline $\begin{array}{l}\text { Number of final } \\
\text { burns }\end{array}$ & $1200-2000$ \\
\hline Wavelength & Green $(532 \mathrm{~nm})$ only \\
\hline
\end{tabular}

Vitrectomy: Several tiny case series have the reportable advantage of vitrectomy within the setting of demonstrable vitreomacular traction and epiretinal proliferation in DME ${ }^{[52-55]}$. Variations in patient populations, the definition of clinically important vitreoretinal traction, surgical approach, use of laser and medications as an adjunct treatment, outcome measures, and follow-up, aboard the customary limitations and biases of retrospective studies, create it troublesome to assess the effectiveness of surgery. The intervention was nonstandardized, with vitrectomy variably in the middle of epiretinal membrane peeling, internal limiting membrane peeling, use of scatter laser, and injection of corticosteroids.

Screening and Surveillance: The recommended schedule for screening and surveillance for NPDR reflects information regarding the epidemiology and natural history of the disease. An initial eye examina- 
tion is suggested five years following diagnosing of type one DM, and at the time of diagnosis for those with type two DM ${ }^{[56]}$. Suggested follow-up examination for persons with type 1 and kind $2 \mathrm{DM}$ with no retinopathy is yearly. within the absence of DME, those with delicate to moderate NPDR ought to be evaluated each 6-12 months, and people with severe NPDR should be seen every 2-4 months, Patients with DME advantage frequent follow-up, usually a minimum of every 2-4 months, Associate in Nursing generally monthly betting on treatment. Any new ocular symptoms ought to prompt timely analysis tailored to the circumstances. A comprehensive eye evaluation, as well as dilated funduscopic examination by an ophthalmologist intimate within the management of diabetic eye disease, remains the quality of taking care of retinopathy screening in areas with adequate access to ophthalmic care.

\section{CONCLUSION}

We have created tremendous progress in managing diabetic retinopathy. Present treatment ways provide vision gain during a vital proportion of patients. Important challenges remain, however. To combat the increasing burden of disease, we tend to should develop higher preventive strategies. To appreciate the advantages of existing treatments, we must greatly improve our success at screening and surveillance for diabetic retinopathy and facilitate access to timely therapy. To develop simpler treatments, we must better understand the biochemical and cellular basis for disease and rationally target key pathways. Proliferative diabetic retinopathy could be a severe sightthreatening complication of diabetes. Whereas PDR cannot be prevented, scatter (panretinal) laser surgery is effective in protecting vision and preventing vision loss. Augmented understandings of the organic chemistry mechanisms underlying PDR are providing new therapeutic approaches with the promise to be each effective and fewer damaging than current photocoagulation techniques. Timely panretinal laser photocoagulation will cut back the danger of severe visual loss by $96 \%$, with long-run preservation of vision. Recent information recommends that anti-VEGF therapy is additionally a secure and effective treatment different for eyes with PDR. Given the advances current within the general and ocular management of diabetes, it's doubtless that the long run of PDR.

\section{REFERENCES}

1. The Diabetes Control and Complications Trial Research Group. The effect of intensive treatment of diabetes on the development and progression of longterm complications in insulin-dependent diabetes mellitus. N Engl J Med. 1993; 329:977-986.

2. UK Prospective Diabetes Study (UKPDS) Group. Intensive blood-glucose control with sulphonylureas or insulin compared with conventional treatment and risk of complications in patients with type 2 diabetes (UKPDS 33). Lancet. 1998; 352:837-853.

3. UK Prospective Diabetes Study Group. Tight blood pressure control and risk of macrovascular and microvascular complications in type 2 diabetes (UKPDS 38). Br Med J. 1998; 317:703-713.

4. Nittala MG, Keane PA, Zhang K, et al. Risk factors for proliferative diabetic retinopathy in a Latino American population. Retina. 2014; 24(8):1594-1599.

5. Davis MD, Fisher MR, Gangnon RE, et al. Risk factors for high-risk proliferative diabetic retinopathy and severe visual loss: Early Treatment Diabetic Retinopathy Study Report \#18. Invest Ophthalmol Vis Sci. 1998; 39(2):233-252.

6. Porta M, Sjoelie AK, Chaturvedi N, et al. Risk factors for progression to proliferative diabetic retinopathy in the EURODIAB Prospective Complications Study. Diabetologia. 2001; 44:2203-2209.

7. Preliminary report on effects of photocoagulation therapy. The Diabetic Retinopathy Study Research Group. Am J Ophthalmol. 1976; 81(4):383-396.

8. Four risk factors for severe visual loss in diabetic retinopathy. The third report from the Diabetic Retinopathy Study. The Diabetic Retinopathy Study Research Group. Arch Ophthalmol. 1979; 97(4):654-655.

9. Mitka M. Report quantifies diabetes complications. JAMA. 2007; 297(21):2337-2338.

10. Klein R, Klein BEK, Moss SE, et al. The Wisconsin Epidemiologic Study of Diabetic retinopathy: II. Prevalence and risk of diabetic retinopathy when age at diagnosis is less than 30 years. Arch Ophthalmol. 1984; 102:527-532. 
11. Klein R, Klein BE, Moss SE, DeMets DL, Kaufman I, Voss PS. Prevalence of diabetes mellitus in southern Wisconsin. Am J Epidemiol. 1984; 119(1):54-61.

12. Klein R, Klein BE, Moss SE, Davis MD, DeMets DL. The Wisconsin Epidemiologic Study of Diabetic Retinopathy. II. Prevalence and risk of diabetic retinopathy when age at diagnosis is less than 30 years. Arch Ophthalmol. 1984; 102(4):520-526.

13. Klein R, Klein BE, Moss SE, Davis MD, DeMets DL. The Wisconsin Epidemiologic Study of Diabetic Retinopathy. III. Prevalence and risk of diabetic retinopathy when age at diagnosis is 30 or more years. Arch Ophthalmol. 1984; 102(4):527-532.

14. Kinoshita JH. Mechanisms initiating cataract formation. Proctor Lecture. Invest Ophthalmol. 1974; 13:713-724.

15. Gabbay KH. Hyperglycemia, polyol metabolism, complications of diabetes mellitus. Annu Rev Med. 1975; 26:521-536.

16. Brownlee M, Vlassara H, Cerami A. Nonenzymatic glycosylation and the pathogenesis of diabetic complications. Ann Intern Med. 1984; 101:527-537.

17. Brownlee M. Advanced protein glycosylation in diabetes and ageing. Annu Rev Med. 1995; 46:223-234.

18. Chibber R, Molinatti PA, Kohner EM. Intracellular protein glycation in cultured retinal capillary pericytes and endothelial cells exposed to high-glucose concentration. Cell Mol Biol. 1999; 45:47-57.

19. Giardino I, Edelstein D, Brownlee M. Nonenzymatic glycosylation in vitro and bovine endothelial cells alters basic fibroblast growth factor activity: a model for intracellular glycosylation in diabetes. J Clin Invest. 1994; 94:110-117.

20. Arden GB, Sidman RL, Arap W, et al. Rod driven hypoxia. Br J Ophthalmol. 2005; 89:764-769.

21. Lin MK, Kim SH, Zhang L, et al. Rod metabolic demand drives progression in retinopathies. Taiwan $\mathbf{J}$ Ophthal. 2015; 1-4.

22. Williamson JR, Chang K, Frangos M, et al. Hyperglycemic pseudohypoxia and diabetic complications. Diabetes. 1993; 42:801-813.

23. Nishikawa T, Edelstein D, Du XL, et al. normalizing mitochondrial superoxide production blocks three pathways of hyperglycaemic damage. Nature. 2000; 404:787- 790.

24. Suzuki S, Hinokio Y, Komatu K, et al. Oxidative damage to mitochondrial DNA and its relationship to diabetic complications. Diabetes Res Clin Pract. 1999; 45:161-168.
25. Hunt JV, Dean RT, Wolff SP. Hydroxyl radical production and autoxidative glycosylation: glucose autoxidation as the cause of protein damage in the experimental glycation model of diabetes mellitus and ageing. Biochem J. 1988; 256:205-212.

26. Xia P, Aiello LP, Ishii H, et al. Characterization of vascular endothelial growth factor's effect on the activation of protein kinase $\mathrm{C}$, its isoforms, endothelial cell growth. J Clin Invest. 1996; 98:2018-2026.

27. Xia P, Inoguchi T, Kern TS, et al. Characterization of the mechanism for the chronic activation of diacylglycerolprotein kinase $\mathrm{C}$ pathway in diabetes and hypergalactosemia. Diabetes. 1994; 43:1122-1129.

28. Nishizuka Y. Intracellular signalling by hydrolysis of phospholipids and activation of protein kinase C. Science. 1992; 258:607-614.

29. Inoguchi T, Battan R, Handler E, et al. Preferential elevation of protein kinase $\mathrm{C}$ isoform beta II and diacylglycerol levels in the aorta and heart of diabetic rats: differential reversibility to glycemic control by islet cell transplantation. Proc Natl Acad Sci USA. 1992; 89:11059-11063.

30. Grading diabetic retinopathy from stereoscopic colour fundus photographs - an extension of the modified Airlie House classification. ETDRS report number 10. Early Treatment Diabetic Retinopathy Study Research Group. Ophthalmology. 1991; 98:786-806.

31. Fundus photographic risk factors for progression of diabetic retinopathy. ETDRS report no. 12. Early Treatment Diabetic Retinopathy Study Research Group. Ophthalmology. 1991; 98:823-833.

32. Early photocoagulation for diabetic retinopathy. ETDRS report no. 9. Early Treatment Diabetic Retinopathy Study Research Group. Ophthalmology. 1991; 98:766-785.

33. Yannuzzi LA, Rohrer KT, Tindel LJ, et al. Fluorescein angiography complication survey. Ophthalmology. 1986; 93:611-617.

34. Fraser-Bell S, Ying-Lai M, Klein R, et al. Prevalence and associations of epiretinal membranes in Latinos: the Los Angeles Latino Eye Study. Invest Ophthalmol Vis Sci. 2004; 45:1732-1736.

35. Kawasaki R, Wang JJ, Sato H, et al. Prevalence and associations of epiretinal membranes in an adult Japanese population: the Funagata study. Eye (Lond). 2009; 23:1045- 1051 .

36. Hofman P, Blaauwgeers HG, Tolentino MJ, et al. VEGF-A induced hyperpermeability of blood-retinal barrier endothelium in vivo is predominantly associat- 
ed with pinocytotic vesicular transport and not with formation of fenestrations. Vascular endothelial growth factor-A. Curr Eye Res. 2000; 21:637-645.

37. Michels S, Rosenfeld PJ, Puliafito CA, et al. Systemic bevacizumab (Avastin) therapy for neovascular agerelated macular degeneration twelve-week results of an uncontrolled open-label clinical study. Ophthalmology. 2005; 112:1035-1047.

38. Moshfeghi AA, Rosenfeld PJ, Puliafito CA, et al. Systemic bevacizumab (Avastin) therapy for neovascular age-related macular degeneration: twenty-four-week results of an uncontrolled open-label clinical study. Ophthalmology. 2006; 113:2002.e1-2002.e12.

39. Nguyen QD, Shah SM, Hafiz G, et al. A phase I trial of an IV-administered vascular endothelial growth factor trap for treatment in patients with choroidal neovascularization due to age-related macular degeneration. Ophthalmology. 2006; 113:1522.e1-1522.e14.

40. Crum R, Szabo S, Folkman J. A new class of steroids inhibits angiogenesis in the presence of heparin or a heparin fragment. Science. 1985; 230:1375-1378.

41. Folkman J, Ingber DE. Angiostatic steroids. Method of discovery and mechanism of action. Ann Surg. 1987; 206:374-383.

42. Gordon DM. Prednisone and prednisolone in ocular disease. Am J Ophthalmol. 1956; 41:593-600.

43. Ingber DE, Madri JA, Folkman J. A possible mechanism for inhibition of angiogenesis by angiostatic steroids: induction of capillary basement membrane dissolution. Endocrinology. 1986; 119:1768-1775.

44. Fauci A. Clinical aspects of immunosuppression: use of cytotoxic agents and corticosteroids. Bellanti JA. Immunology II. WB Saunders: Philadelphia; 1978.

45. Nussenblatt R, Whitcup S, Palestine A. Uveitis: fundamentals and clinical practice. Mosby: St. Louis; 1996.

46. Early Treatment Diabetic Retinopathy Study Research Group. Photocoagulation for diabetic macular oedema. Early Treatment Diabetic Retinopathy Study report number 1. Arch Ophthalmol. 1985; 103:1796-1806.

47. Early Treatment Diabetic Retinopathy Study design and baseline patient characteristics. ETDRS report number 7. Ophthalmology. 1991; 98:741-756.

48. Ederer F, Hiller R. Clinical trials, diabetic retinopathy and photocoagulation. A reanalysis of five studies. Surv Ophthalmol. 1975; 19(5):267-286.

49. Editorial: The Diabetic Retinopathy Study. Arch Ophthalmol. 1973; 90(5):347-348.
50. Photocoagulation treatment of proliferative diabetic retinopathy. Clinical application of Diabetic Retinopathy Study (DRS) findings, DRS report number 8. The Diabetic Retinopathy Study Research Group. Ophthalmology. 1981; 88(7):583-600.

51. Techniques for scattering and local photocoagulation treatment of diabetic retinopathy: Early Treatment Diabetic Retinopathy Study report no. 3. The Early Treatment Diabetic Retinopathy Study Research Group. Int Ophthalmol Clin. 1987; 27(4):254-264.

52. Harbour JW, Smiddy WE, Flynn HW Jr, et al. Vitrectomy for diabetic macular oedema associated with a thickened and taut posterior hyaloid membrane. Am J Ophthalmol. 1996; 121:405-413.

53. Kaiser PK, Riemann CD, Sears JE, et al. Macular traction detachment and diabetic macular oedema associated with posterior hyaloidal traction. Am J Ophthalmol. 2001; 131:44- 49.

54. Lewis H, Abrams GW, Blumenkranz MS, et al. Vitrectomy for diabetic macular traction and oedema associated with posterior hyaloidal traction. Ophthalmology. 1992; 99:753-759.

55. Pendergast SD, Hassan TS, Williams GA, et al. Vitrectomy for diffuse diabetic macular oedema associated with a taut premacular posterior hyaloid. Am J Ophthalmol. 2000; 130:178-186.

56. American Academy of Ophthalmology Retina Panel. Preferred Practice Pattern ${ }^{\circledR}$ guidelines: Diabetic retinopathy. [San Francisco, CA: AAO] http://www.aao.org/preferred practicepattern/diabetic-retinopathy-PPP--2014; 2014.

\section{Source of Support: Nil \\ Conflict of Interest: None Declared}

How to cite this URL: Narender Chanchal et al: Prevalence, Pathogenesis, Classification, Imaging, Screening And Manage-Ment Of Diabetic Retinopathy- A Critical Review. International Ayurvedic Medical Journal \{online\} 2021 \{cited July 2021\} Available from: http://www.iamj.in/posts/images/upload/1433_1442.pdf 